\title{
Evaluation of plant species suitability for lowland forest landscape restoration in Lepan watersheds, Langkat District, North Sumatra, Indonesia
}

\author{
SAMSURI ${ }^{1, \boldsymbol{v}}$, ALFAN GUNAWAN AHMAD ${ }^{2}$, ANITA ZAITUNAH ${ }^{1}$, HALIZA KHAIRUNI TAMBUSAI ${ }^{1}$ \\ ${ }^{1}$ Department of Forest Management, Faculty of Forestry, Universitas Sumatera Utara. Jl. Tri Dharma Ujung No. 1, Kampus USU, Medan 20155, North \\ Sumatra, Indonesia. Tel./fax.: + 62-61-8220605, `email: gsamsuri@gmail.com \\ ${ }^{2}$ Department of Forest Conservation, Faculty of Forestry, Universitas Sumatera Utara. Jl. Tri Dharma Ujung No. 1, Kampus USU, Medan 20155, North \\ Sumatra, Indonesia
}

Manuscript received: 18 March 2019. Revision accepted: 9 September 2019.

\begin{abstract}
Samsuri, Ahmad AG, Zaitunah A, Tambusai HK. 2019. Evaluation of suitability of plant species for lowland forest landscape restoration in Lepan watersheds, Langkat District, North Sumatra, Indonesia. Biodiversitas 20: 2903-2909. Lepan watersheds have high management priority in North Sumatra due to healthy biophysical, socio-economic conditions and issues. Many human activities, such as conversion of forest land into settlements and oil palm plantations have resulted in decreasing the ecological functions of the forest landscape. Therefore, it is necessary to initiate efforts and actions to preserve the environment in order to prevent further damage. The effort required is to restore the already damaged ecosystem with the cultivation of species of plants in accordance with the land and soil conditions of the Lepan watersheds. Four criteria are used for determining suitable plants that can be planted as well as cultivated by the community. They are plant species found in natural forests, plant species meeting the physical and soil characteristics, plant species cultivated by community and plant species based on community perceptions. Species matching was determined by scoring and weighting method. This study found that the most suitable species for restoration activities based on these four criteria is Pterospermum subpeltatum.
\end{abstract}

Keywords: Forest landscape, Lepan watersheds, species matching, restoration

\section{INTRODUCTION}

Forest degradation in Indonesia has now reached 1.82.8 million hectares per year. Until 2005, the total of degraded forest area was around 56.62 million ha (Kuswanda and Sukmana 2009) that are 4.42 million ha of forest production, 10.52 million ha protected forest and 4.69 million ha conservation forest area. Forest degradation caused by human activities can accelerate the decreasing trend of ecosystems services. Forest land is converted to cultivation land and also for various activities needed for fulfilling human needs, causing significant reduction of biodiversity. The physical, chemical and biological conditions of the soil also getting worsened. In order to avoid further damage, there is an urgent need for actions related to environment conservation. These efforts can be pursued by restoring the already degraded ecosystems. This effort is expected to repair the damaged ecosystems so that they get restored. The current damage to forest resources has resulted in disruption of environmental balance in watersheds, causing problems such as floods, erosion, drought, and silting of rivers, reservoirs and irrigation canals.

The functions of forest ecosystem will be better performed when the forest landscape encompasses a watershed growing well and covering enough forest area. According to the Minister of Forestry Decree No. SK.328/Menhut-II/2009, there are 108 priority watersheds in Indonesia, one of them is Lepan watershed located in Langkat Regency, North Sumatra Province. Forest cover area of Lepan watershed has decreased by 3,424.59 ha during the period between 2005 and 2015. Large number of conversions of forest land into settlements and oil palm plantations, was one of the causes for the decline of forest area in the Lepan watersheds (Meliala et al. 2016; Zaitunah et al. 2019). This has changed the conditions of land use and vegetation as well as biomass and carbon storage in the watersheds. This phenomenon warrants immediate attention to and handling of various aspects related to the management of Lepan watersheds.

Restoration planning is crucial in determining the strategy for the implementation of restoration of damaged ecosystems (Arronson et al. 2007; Samsuri 2014). Selection of appropriate species for restoration activities that can restore the linkages between integral ecosystems is also important. Restoration of degraded forests is critical to human life and well-being as it affects long-term food needs, climate stability, and biodiversity conservation. To run the restoration activity successfully, training and capacity-building are needed, especially at large scales (Clewell and Aronson 2007). Restoration can prevent land degradation and increase land productivity. Restoring degraded land will also create a rich, productive and robust carbon-rich land. It will be obtained when restoration activities emphasises on achieving maximum economic benefits (Orsi 2011). 
Critical step of any ecological restoration activity is determining the right species to be planted. In addition to considering natural forest landscape species, it also has to correspond with community preferences because they have important role in success of any restoration project (Arronson et al. 1995; Lamb et al. 2005). Ecological restoration in a small farm has to consider the socioeconomic interests of small local farmers (Arronson et al. 2010). Analysis of suitability of plant species should be conducted before implementing any forest landscape restoration project. In this research, suitability of the species was analyzed to find out the crops suitable for the soil characteristics of the Lepan watersheds.

\section{MATERIALS AND METHODS}

\section{Location and time of study}

This research was conducted in Lepan watersheds, Langkat District, North Sumatra Province, Indonesia. Physical and chemical analysis of soil was conducted at Agricultural Central Laboratory, Faculty of Agriculture, North Sumatra University, Medan, Indonesia. The research was carried out for a period of 12 months, from May 2016 to July 2017. Lepan watershed has priority status to be rehabilitated covering an area of about 57,407,75 ha. This watershed is situated 300-700 meter above sea level. Geographically, Lepan watershed is located between $3^{\circ} 42^{\prime}$ $42,96^{\prime \prime}-4^{\circ} 04^{\prime} 34,96^{\prime \prime}$ North and $98^{\circ} 00^{\prime}, 43^{\prime \prime}-98^{\circ} 24^{\prime} 16,30^{\prime \prime}$ East.

\section{Sampling methods}

Vegetation sampling

The data was collected by measurement of vegetation and soils taken from some representative plots. Plots were distributed proportionally into 4 (four) villages in Lepan watershed namely, Harapan Baru Village, Tangkahan Durian Village, Bukit Mas Village, and Harapan Makmur Village. These villages encompassed areas of Lepan watershed and close to Gunung Leuser National Park. Sample plots were selected by using purposive sampling, representing vegetation types such as natural forest, mixed garden, and estate forest. Vegetation data collected were tree diameter and number of trees, saplings, and poles. Vegetation measurements were performed by line strip sampling. The strips were 20 meters wide and long according to field conditions. The sample subplots are placed alternately, each at 20-meter distance, to measure tree growth rates and regeneration levels (tree, saplings, and poles). The subplots design is illustrated in Figure 1.

\section{Soil sampling}

Soil sampling was conducted randomly in the vegetation analysis plots and also in bare land. Soil samples collected were both compact soil samples and composite soil samples.

Compact soil sample. Compact soil sampling was carried out by (i) first determining the soil sampling site from a homogeneous location, (ii) clearing the soil sampling site from coverage plants, (iii) soil sample ring was forced into the soil surface, (iv) the ring with soil was picked up, (v) the ring was cleaned with a knife and labeled. The soil samples were then analyzed in the laboratory to examine its physical properties, soil texture, and bulk density.

Composite soil samples. The composite soil sampling was conducted in the following way: (i) approximately 1-2 $\mathrm{kg}$ of disturbed soil samples were collected from several points randomly by making holes at a depth of $0-20 \mathrm{~cm}$ (subsoil), (ii) then the soil samples were put into plastic bags, fastened and labeled, (iii) soil was mixed while stirring until evenly and cleaned from the remnants of the plant or roots, inserted it into a large plastic and labeled, and (iv) the soil samples were analyzed in the laboratory to examine the soil chemical properties.

\section{Community interview}

Plant species suitability also was determined by community perception. Community perception of plant species was evaluated by interview with questioners to some respondents from four villages samples. Therefore, plant species recommended by respondent were tabulated and scored.

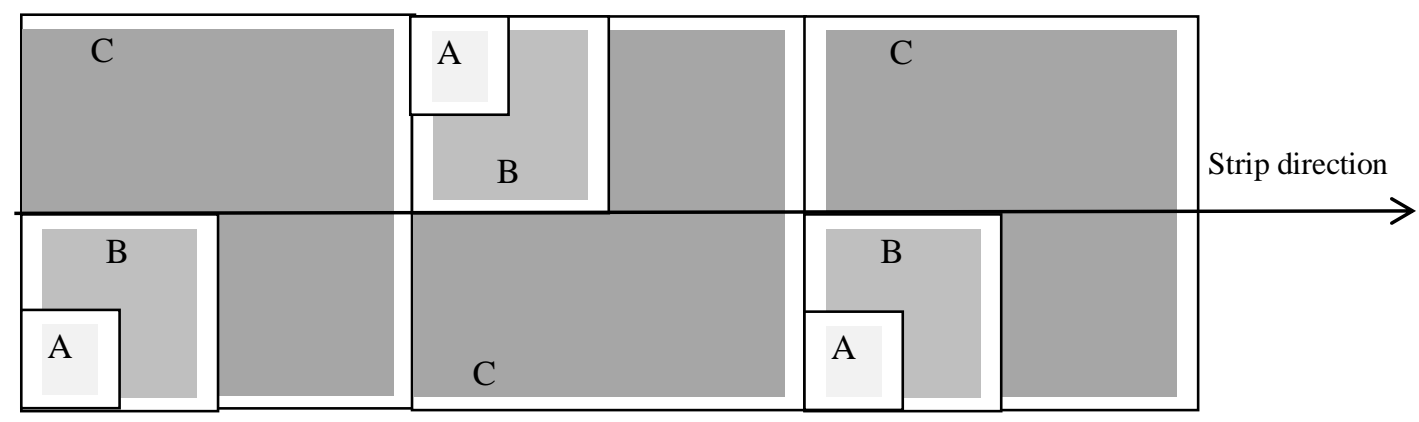

Figure 1. Sample plot design: Sample plot A: Subplot of $5 \mathrm{~m}$ x $5 \mathrm{~m}$ size for sapling stage, B: Subplot of $10 \mathrm{~m}$ x $10 \mathrm{~m}$ size for pole stage, C: Subplot of $20 \mathrm{~m}$ x $20 \mathrm{~m}$ size for tree stage 


\section{Data analysis}

Species composition

Important value index (IVI) was determined to find out the dominant species at each growth stage, from relative density, relative frequency and relative dominance calculated based on the following equation:

Density per ha $=\frac{\text { total mumber of number species } x 10000 \mathrm{~m}^{2}}{\text { total mumber of quadrat studied } x \text { area of quadrat }}$

Relative density $=\frac{\text { density per ha of a species }}{\text { total mumber of density all species }} \times 100 \%$

Frequency of species $=\frac{\text { total mumber of quadrat in which species found }}{\text { total number of quadrat studied }}$

Relative frequency $=\frac{\text { frequency of a species }}{\text { total mumber of frequency all species }} \times 100 \%$

Basal area $\left(\mathrm{m}^{2}\right)=\frac{2}{4} \times 3,1416 \times(\text { diametre })^{2}$

Dominance $=\frac{\text { basal area of a species }}{\text { total number of quadrat studied }}$

Relative dominance $=\frac{\text { dominance of a species }}{\text { total dominance of all species }} \times 100 \%$

Important Value Index $x_{\text {tree }}=$ Relative density + Relative frequency + Relative dominance

Important Value Index $x_{\text {seedling,sapling }}=$ Relative density + Relative frequency

Physical and chemical characteristics of soil

Physical and chemical characteristics of soil analyzed were soil texture using Hydrometer method (Ashworth et al. 2001), Cation Exchange Capacity (CEC) with NH4OAc Extraction Method, C-Organic using Walkley and Black method, N-Total by Kjeldahl Method (Balai Penelitian Tanah 2009) and $\mathrm{pH}$ by Electrometric Method (Luzana et al. 1971). After obtaining soil physical and chemical characteristics data, adjusted to the data of land suitability criteria of some types of plants, then scored in accordance with the land class from the characteristic data obtained based on the land characteristic matrix as in Table 1.

\section{Determining the suitable plant species for restoration}

After knowing the most suitable plants based on important value index, soil characteristics, community preference, and cultivated species, scoring is implemented for each plant. Assessment of scores for each plant was based on four criteria used to determine the appropriate plant species for restoration activities. Each criterion was assigned a weighted value based on the Regulation of the Minister of Forestry of the Republic of Indonesia No: P.70 / Menhut II/2008 which specifies the composition of plant species for protection forest in reforestation activities as minimum $60 \%$ of timber and maximum $40 \%$ of multipurpose tree species (wood, sap, fruit ) wherever it is distributed into three criteria (b1, b3, and b4) (MoF 2008). Based on these references, the weight age of scores for each criterion is shown in Table 2.
Table 1. Score matrix of land suitability Wardhani 2011)

\begin{tabular}{lccccc}
\hline Parameter & S1 & S2 & S3 & N1 & N2 \\
\hline Texture & 5 & 4 & 3 & 2 & 1 \\
KTK & 5 & 4 & 3 & 2 & 1 \\
pH & 5 & 4 & 3 & 2 & 1 \\
C-Organic & 5 & 4 & 3 & 2 & 1 \\
Al & 5 & 4 & 3 & 2 & 1 \\
N Total & 5 & 4 & 3 & 2 & 1 \\
\hline
\end{tabular}

Notes: $\mathrm{S}=$ suitable (consist of 3 class); $\mathrm{N}=$ not suitable (consist of 2 class)

Table 2. Weighted value on each criterion

\begin{tabular}{lll}
\hline $\begin{array}{l}\text { Weighted } \\
\text { value }\end{array}$ & Criteria & $\begin{array}{l}\text { Percentage } \\
(\%)\end{array}$ \\
\hline b1 & $\begin{array}{l}\text { Species of plant cultivated by } \\
\text { community }\end{array}$ & 13.3 \\
b2 & $\begin{array}{l}\text { Species of natural forest } \\
\text { b3 }\end{array}$ & $\begin{array}{l}\text { Species of plant with soil } \\
\text { characteristics }\end{array}$ \\
b4 & $\begin{array}{l}\text { Species of plant chosen by } \\
\text { community preferences }\end{array}$ & 13.3 \\
& & 13.3 \\
\hline
\end{tabular}

Note: $b_{1}, b_{2}, b_{3}, b_{3}=$ weighted of each criterion

The formula for determination of suitable plant species based on different criteria for restoration activities is a modification of formula provided by Salim et al. (1999). The criteria used are the most widely cultivated species of plants, the types of plants that exist in natural forests, types of plants based on physical characteristics and soil chemistry, and types of plants based on community perceptions.

$$
Y i j=\sum\left[b_{i} x k_{i}\right]
$$

Note:

$\mathrm{Y}_{\mathrm{ij}}=$ total score of tree species

$b_{i}=$ weighted value of each criterion in species alternative-i

$\mathrm{k}_{\mathrm{j}}=$ score of plant species $-\mathrm{j}$

\section{RESULTS AND DISCUSSION}

\section{Plants cultivated by communities}

Types of crops cultivated by the community refer to species planted by local people surrounding their home yards. Table 3 shows ten dominant species that are cultivated in Lepan watershed. Hevea brasilliensis is dominant species having highest IVI, meanwhile, Artocarpus heterophyllus has the lowest IVI. The type of cultivated plants vary according to the choices and needs of the community. Community preferred H. brasilliensis because this plant has benefits as an income source for household and also has been recognized as an oxygen provider. 
Table 3. Plant species are grown surrounding home yards

\begin{tabular}{llccc}
\hline Local name & Scientific name & IVI & Score & $\begin{array}{c}\text { Score* } \\
\text { weighted }\end{array}$ \\
\hline Karet & Hevea brasilliensis & 150 & 10 & 1.333 \\
Kakao & Theobroma cacao & 127 & 9 & 1.197 \\
Durian & Durio zibethinus & 70 & 8 & 1.064 \\
Jabon & Anthocephalus cadamba & 41 & 7 & 0.931 \\
Gmelina & Gmelina arborea & 36 & 6 & $0 ., 798$ \\
Petai & Parkia speciose & 27 & 5 & 0.665 \\
Rambutan & Nephelium lappaceum & 25 & 4 & 0.532 \\
Cempedak & Artocarpus integer & 16 & 3 & 0.399 \\
Sawo kecik & Manilkara kauki & 13 & 2 & 0.266 \\
Nangka & Artocarpus heterophyllus & 10 & 1 & 0.133 \\
\hline
\end{tabular}

Table 4. Plant types based on physical and chemical characteristics of soil

\begin{tabular}{llccc}
\hline $\begin{array}{l}\text { Local } \\
\text { name }\end{array}$ & Scientific name & $\begin{array}{c}\text { Total } \\
\text { score }\end{array}$ & Score & $\begin{array}{c}\text { Score* } \\
\text { weighted }\end{array}$ \\
\hline Karet & Hevea brasilliensis & 547 & 10 & 1.333 \\
Rambutan & Nephelium lappaceum & 509 & 9 & 1.197 \\
Durian & Durio zibethinus & 409 & 8 & 1.064 \\
Kakao & Theobroma cacao & 388 & 7 & 0.931 \\
Ekaliptus & Eucalyptus grandis & 210 & 6 & 0.798 \\
Jabon & Anthocephalus cadamba & 209 & 5 & 0.665 \\
Mahoni & Swietenia mahagoni & 202 & 4 & 0.532 \\
Jati & Tectona grandis & 202 & 3 & 0.399 \\
Damar & Agathis dammara & 202 & 2 & 0.266 \\
Rasamala & Altingia excelsa & 196 & 1 & 0.133 \\
\hline
\end{tabular}

Table 5. Dominant plant species identified in natural forest

\begin{tabular}{llccc}
\hline Local name & Scientific name & \multicolumn{2}{c}{ IVI Score } & $\begin{array}{c}\text { Score* } \\
\text { weighted }\end{array}$ \\
\hline Bayur & Pterospermum subpeltatum & 70 & 10 & 6.0 \\
Matoa & Pometia pinnata & 51 & 9 & 5.4 \\
Klempen simpur & Nephelium lappaceum & 38 & 8 & 4.8 \\
Meranti & Shorea sp. & 37 & 7 & 4.2 \\
Benoang & Octomeles sumatrana & 37 & 6 & 3.6 \\
Meranti Batu & Shorea dasyphylla & 33 & 5 & 3.0 \\
Gusi Biang & Salvadora persica & 31 & 4 & 2.4 \\
Marak bangkong & Macaranga indica & 28 & 3 & 1.8 \\
Jengkol & Archidendron pauciflorum & 26 & 2 & 1.2 \\
Durian & Durio zibethinus & 25 & 1 & 0.6 \\
\hline
\end{tabular}

Table 6. Plant species based on community perception in Lepan watersheds

\begin{tabular}{llccc}
\hline Local name & \multicolumn{1}{c}{ Scientific name } & $\begin{array}{c}\text { Total } \\
\text { voter }\end{array}$ & Score & $\begin{array}{c}\text { Score* } \\
\text { weighted }\end{array}$ \\
\hline Karet & Hevea brasilliensis & 24 & 10 & 1.333 \\
Jeruk & Citrus $x$ sinensis & 16 & 9 & 1.197 \\
Rambutan & Nephelium lappaceum & 14 & 8 & 1.064 \\
Cempedak & Artocarpus integer & 14 & 7 & 0.931 \\
Damar & Agathis dammara & 11 & 6 & 0.798 \\
Durian & Durio zibethinus & 9 & 5 & 0.665 \\
Mahoni & Swietenia mahagoni & 3 & 4 & 0.532 \\
Jabon & Anthocepalus cadamba & 2 & 3 & 0.399 \\
Jati & Tectona grandis & 2 & 2 & 0.266 \\
Merbau & Intsia bijuga & 1 & 1 & 0.133 \\
\hline
\end{tabular}

Plants based on physical and chemical characteristics of soil

Analysis based on the physical and chemical characteristics of the soil shows the suitable plant species that can be cultivated in the Lepan watershed as listed in Table 4. Some of the most cultivated crops in the Lepan watersheds were sorted according to land suitability matrix scores. Trees selected with highest total score based on these criteria are H. brasilliensis, Nephelium lappaceum, and Durio zibethinus. Field observations also found that $H$. brasiliensis was growing very well. This finding is quite different from common criteria used i.e. tree species selected based on tolerance to poor soils and quick establishment of canopy cover in degraded environments (Cao et al. 2011). The research areas have fertilized soils, according to community information.

\section{Species composition of natural forest}

Sampling data of natural forest indicated 10 plant species as the most dominant species in natural forest. They are found in the remaining natural forests of Lepan watershed. These species listed according to their ranks in Table 5. Pterospermum subpeltatum, Pometia pinnata, N. lappaceum and the other dominant species could be used for restoration activity also because it will be easy to obtain their natural seedlings. In order to prevent more degradation of forest and maintenance of forest as wildlife habitat, the degree of fragmentation and connectivity should be considered as priority for forest restoration areas (Samsuri et al. 2014). The use of natural forest species is alternative to government support to programs of increasing forest area but most of the increase in single species and tree plantations with lower average of growing stock (Lin 2012).

\section{Plants species based on community perceptions}

In addition to data obtained from field observations, data on plants based on community perceptions were also collected in the study area (Table 6). The community has an important role to play in restoration activities, therefore it is necessary to have data on the crops people choose as supporting to restoration activities that serve to repair degraded land. Generally, community has chosen species listed in table 6 for cultivating because these species can give alternative income for them.

\section{Plant species matching}

Appropriate plant type for restoration in Lepan watershed was determined by scoring of four (4) factors e.g. (i) plant species cultivated by community, (ii) plant species found in mixed garden, (iii) plant species suited with soil characteristics and (iv) plant species figured in natural forest. It is known that some plants have the highest score (weighted*score). The plant species obtaining highest scores based on these four categories are the most suitable for restoration activities in the Lepan watersheds (Table 7). Table 7 shown seven natural forest species that are $P$. subpeltatum, P. pinnata, Dillenia indica, Shorea sp., Octomeles sumatrana, D. zibethinus, Shorea dasyphylla, and Salvadora persica. Meanwhile, there are four MPTS suitable species that are $P$. pinnata, H. brasilliensis, D. zibethinus, and N. lappaceum. 
Table 7. The most suitable plant species in the Lepan watersheds base on four criteria

\begin{tabular}{llc}
\hline Local name & Scientific name & $\begin{array}{c}\text { Score* } \\
\text { weighted }\end{array}$ \\
\hline Bayur & Pterospermum subpeltatum & 6,000 \\
Matoa & Pometia pinnata & 5,400 \\
Klemper simpur & Dillenia indica & 4,800 \\
Meranti & Shorea sp & 4,200 \\
Karet & Hevea brasilliensis & 3,999 \\
Benoang & Octomeles sumatrana & 3,600 \\
Durian & Durio zibethinus & 3,393 \\
Meranti batu & Shorea dasyphylla & 3,000 \\
Rambutan & Nephellium lappaceum & 2,793 \\
Gusi biang & Salvadora persica & 2,400 \\
\hline
\end{tabular}

\section{Discussion}

Plants based on Lepan watersheds condition

Plant species with higher IVI values are the most suitable plant species to be cultivated in the Lepan watersheds. A few plants have highest IVI values in each study village of Lepan watersheds. Rubber ( $H$. brasilliensis) is the most popularly cultivated plant with an IVI value of 150 and a score of 1.333 as shown in Table 3. Rubber plants have many economic benefits, therefore, most people cultivate this plant. Rubber is also a suitable plant to be grown in Lepan watershed because it is classified as plant that can improve soil quality from bare land (Wauters et al. 2008). This is in line with the statement of Arsyad (1989) suggesting that tree species to be planted in degraded land should meet the following criteria: fast-growing plant species, generating large litter, having a wide and strong root system, having economic value, improving soil, and having a dense canopy. Besides rubber, plants widely cultivated in the home gardens are MPTS species. These species of plants provide direct benefits to the community and the surrounding environment, such as edible fruits, the branches can be used for firewood, and the litter can fertilize the soil.

Generally, community living in and surrounding watershed areas have planted variety of tree species. They are an income source and are harvested for wood or nonwood forest products. The community knows that plants have benefits as carbon sink and also have economic value. For example, multipurpose tree species (MPTS) can be utilized for fruits, stems, leaves, etc. The species of cultivated plants vary according to the choices and needs of the community. It is in line with the expert knowledge of stakeholders who were used to understand the key types of ecosystem services. So, the species used for restoration should also consider the valued ecosystem services that timber products and wood-fuels such as biomass to electricity, and grazing (Stafford 2019). The need for livestock grazing is increasing due to population growth, as well as cultural and social preference. Meanwhile promoting ecological restoration need incentives such as payments for biodiversity protection and enhancement of ecosystem services provided by restored tropical ecosystems (Rodriguesa 2011).
Field observation in Bukit Mas Village found that most widely cultivated species was rubber (H. brasilliensis). It is proven that the rubber has the highest IVI values (Table 3). Another plant having high IVI value of 70 was $D$. zibethinus. Meanwhile, D. zibethinus was cultivated by community because it has delicious fruits having good market price. Similar to Bukit Mas Village, Harapan Makmur Village has $H$. brasilliensis as the most cultivated species. Rubber is widely cultivated because it has many benefits for both society and the environment. This is in accordance with the statement of Simien and Penot (2011) which states that $H$. brasilliensis has many functions, one of which is the production function. It serves as the raw material for the making of many objects and equipment used by the locals. In addition to production functions, rubber also has a positive impact on the soil, because it can prevent erosion and landslides, as well as litter from rubber leaves can fertilize the soil and as carbon sink (Wauters et al. 2008). This condition also occurred in Tangkahan Durian Village, where the community widely cultivated $H$. brasilliensis. Meanwhile, they also cultivated gmelina (Gmelina arborea) having an IVI value of $36 \%$.

Different from other three villages, Anthocepalus cadamba is cultivated by many people in Harapan Baru Village. A. cadamba also has the highest IVI of 41. Similar to D. zibethinus, A. cadamba is widely cultivated by the community because it has high economic and ecological value. According to Bijalwan et al. (2014), A. cadamba is a plant that grows faster, can adapt to various growing places, and tends to be free from attacks of pests and serious diseases. A. cadamba wood also has a high economic value because it can be used as raw materials for plywood, light construction, pulp and paper, and so forth.

Interviews conducted with community regarding important plants cultivated found that the most cultivated species is rubber, as well as many people in the Lepan watershed area work as rubber farmers. A few natural forest species were also still found around the yards of the community, but the community does not have knowledge about the functions of these natural forest species. So that they didn't choose natural forest species to be cultivated. People cultivate plant species corresponding with their knowledge and experience and, the capability and capacity of the land are not considered. The requirement of plant species should be met with land capability (Kadir et al. 2016). So, this study has attempted to find plant species which are matching with physical and chemical characteristics of the soil. Good soil conditions will affect the growth of existing plants (Strobla et al. 2018). Each plant has specific growth requirements which are a criterion based on the physical and chemical properties of soil (Milligan 2018; Hardjowigeno et al. 2007). Accordingly, in Harapan Baru Village, the most suitable plant species are $N$. lappaceum and $H$. brasiliensis. Meanwhile, in Bukit Mas Village, the most suitable plant species is $H$. brasiliensis. This is based on the land suitability matrix scores for each land sampling site (Zhanga et al. 2015). Like Harapan Baru Village, $H$. brasiliensis and $N$. lappaceum are the most suitable species for Tangkahan Durian Village also. Among the eight land 
sampling sites, land characteristics of five locations are most suitable for $H$. brasiliensis, while the other three are suitable for N. lappaceum.

In Harapan Makmur Village also, $H$. brasiliensis is the most suitable plant based on soil physical and chemical characteristics. Thus, in all four villages of the Lepan watersheds, the most suitable plant species for restoration based on the physical and chemical characteristics of the soil are $H$. brasilliensis and $N$. lappaceum. Rubber plants can grow in many soil types, with a near neutral $\mathrm{pH}$ between 5-6 (Damrongrak et al. 2015). Basically, the growth of the plant is not dependent on the location and condition of the soil, because the soil conditions can be formed in accordance with the way of good management. However, rambutan plants can grow well on fertile soils containing little sand, and lots of organic matter. The soil $\mathrm{pH}$ corresponding to the rambutan plant is 5.5-6.7 (Orwa 2009, Tipathi and Karunakran 2013).

Selection of plant species for restoring degraded land needs to meet requirements such as, ability to grow in high and full irradiation, ability to compete with Imperata cylindrica and quickly cover the soil, easy to sprout after being burned or trimmed, availability of seeds or vegetative parts for easy breeding, and they must be also favored by the community. In addition, other factors that need to be considered for successful recovery of degraded lands or critical lands are the suitability between land quality and selected species growth requirements (Purwanto et al. 2018).

Restoration activities are aimed to restore forest landscapes almost close to natural conditions, so that more natural species of plants have to be planted. Table 5 shows the ten tree species-having the highest IVI value. These species are native plants of the Lepan watersheds. Some species that exist in the forests are rarely found because of the number of community activities such as the clearing of forest land for accommodating settlements. Communities around the forest also change the natural forest stands into plantation crops and MPTS, this causes the reduction of native species that existed in the area (Rodreguesa et al. 2011).

Based on the community perceptions as listed in Table 6 , rubber is the most preferred plant, as some communities in and around the Lepan watersheds are rubber farmers. Many people choose rubber plant for restoration activities because of its matches with their profession as rubber farmers. Community perception for selecting species to be used in restoration is very important. Orsi at al (2010) state that it's very important to consider human living conditions while making restoration plans because economic, as well as ecological aspects of local people, play important roles in such activities. Meanwhile ecological and socioeconomic impacts need a long time to occur (Lin et al. 2012). Its impact is dependent on the suitability of the tree species for the local environment (Cao et al. 2011). So, there is a need for matching process between the tree species and site conditions on forest restoration planning. Therefore, ecosystem services, social and economic factors have to be considered in restoration planning to achieve long-term success. To accelerate growing of tree used in restoration activity, maximizing economic profits for farmers should be an important consideration for the future (Orsi et al. 2010).

\section{The most suitable plant type for restoration in Lepan watersheds}

So, the tops species of list with highest score is $P$. subpeltatum. This is one of the typical plants from the tropics that can be used by the community as a traditional drug believed to be against dysentery, toothache, ulcers and itching (Salempa 2014). Economically, P. subpeltatum has been chosen because its wood is classified into the durable class IV (Yusran et al. 2011) and, strong class II and III. In addition, this plant also has the ecological function that it can increase fertility of the soil.

Pterospermum subpeltatum can grow well in altitudes up to $600 \mathrm{~m}$ above sea level with an average rainfall of $1000-4000 \mathrm{~mm}$ per year and a temperature of $18-32^{\circ} \mathrm{C}$. $P$. subpeltatum is very sensitive to lack of water, so the soil should have proper storage and availability of water and drainage channels should be performing well. Regarding suitable soil conditions, $P$. subpeltatum needs locations with light to medium soil texture. These plants require good sunlight intensity or cannot grow under intolerance (Purbopuspito 2005).

In conclusion, the research found that (i) The most widely cultivated plants in the Lepan watersheds is $H$. brasilliensis, (ii) The most suitable plant species based on physical and chemical characteristics of the soil in the Lepan watersheds are $H$. brasilliensis and N. lappaceum, and (iii) The most suitable plant species for restoration activities is $P$. subpeltatum.

\section{ACKNOWLEDGEMENTS}

The authors would like to thank the Directorate of Research and Community Services, Technology Research and Higher Education Ministry, Indonesia for funding this research through the "PUPT Grant Scheme"

\section{REFERENCES}

Aronson J, Blignaut JN, Milton SJ, Le Maitre D, Esler KJ, Limouzin A, Fontaine C, de Wit MP, Mugido W, Prinsloo P, van der Elst L, Lederer N. 2010. Are socioeconomic benefits of restoration adequately quantified? A meta-analysis of recent papers (2000-2008) in Restoration Ecology and 12 other scientific journals. Rest Ecol 18: 143-154.

Aronson J, Dhillion S, Le Floc'h E. 1995. On the need to select an ecosystem of reference, however imperfect: a reply to Pickett and Parker. Rest Ecol 3: 1-3.

Aronson J, Milton SJ, Blignaut JN. 2007. Restoring Natural Capital: Science, Business and Practice. Island Press, Washington, DC.

Arsyad S. 1989. Soil and Water Conservation. IPB Press, Bogor. [Indonesian]

Ashworth J, Keyes D, Kirk R, Lessard R. 2001. Standard procedur in the hydrometer method for particle size analysis. Commun Soil Sci Plant Anal 32 (5-6): 633-642.

Balai Penelitian Tanah. 2009. Petunjuk Teknis Analisis Kimia Tanah, Tanaman, Air dan Pupuk. Balai Penelitian Tanah, Badan Penelitian dan Pengembangan Pertanian. Departemen Pertanian, Bogor. [Indonesian] 
Bijalwan A, Dobriyal MJR, Bhartiya JK. 2014. A potential fast growing tree for agroforestry and carbon sequestration in India: Anthocephalus cadamba (Roxb.) Miq. Am J Agric For 2 (6): 296-301.

Cao SX, Chen L, Shankman D, Wang CM, Wang XB, Zhang H. 2011. Excessive reliance on afforestation in China's arid and semi-arid regions: lessons in ecological restoration. Earth-Sci Rev 104: 240-245

Clewell AF, Aronson J. 2007. Ecological Restoration: Principles, Values, and Structure of an Emerging Profession. Island Press, Washington DC.

Damrongrak I, Onthong J, Nilnond C. 2015. Effect of fertilizer and dolomite applications on growth and yield of tapping rubber trees. Songklanakarin J Sci Technol 37 (6): 643-650

MoF. 2008. Forestry Ministry Decree of Indonesian Republic Number: P.70/Menhut II/2008. 2008 Technical Guide for Forest and Land Rehabilitation. [Indonesian]

Hardjowigeno, Sarwono, Widiatmaka. 2007. Evaluation of land suitability and land use planning. Gadjah Mada University Press, Yogyakarta. [Indonesian]

Purbopuspito J. 2005. Trace gas emissions from forest and land-use systems at the tropical forest margins in Central Sulawesi, Indonesia. Cuvillier Verlag, Gottingen

Kadir S, Nurlina, Ridwan I, Rianawati F. 2016. The recovery of Tabunio Watershed through enrichment planting using ecologically and economically valuable species in South Kalimantan, Indonesia. Biodiversitas 17: 140-146

Kuswanda W, Sukmana A. 2009. Species matching for enrichment of degraded orangutan in buffer zone of nature reserve, Dolok Sibual Buali. Jurnal Penelitian Hutan dan Konservasi Alam 6 (2): 125-139. [Indonesian]

Lamb D, Erskine PD, Parrotta JA. 2005. Restoration of degraded tropical forest landscapes. Science 310: 1628-1632.

Lin H, Quanqin S, Jiyuan L. 2012. Forest restoration to achieve both ecological and economic progress, Poyang Lake basin, China. Ecol Eng 44: 53-60.

Luzana M, Perrella M, Bernardi R. 1971. An electrometric method for measurement of small $\mathrm{pH}$ changes in biological systems. J Anal Biochem 43 (2): 556-563.

Meliala WC. 2016. Vegetation Density Analysis on land Cover Types in Lepan Watershed. [Thesis]. Universitas Sumatera Utara, Medan. [Indonesian]

Milligan G, Booth KE, Cox ES, Pakeman RJ, Le Duc MG, Connor L, Blackbird S, Marrs RH. 2018. Change to ecosystem propertie through changing the dominant species: Impact of Pteridium aquilinum-control and heathland restoration treatments on selected soil properties. J Environ Manag 207: 1-9.

Orsi F, Geneletti D. 2010. Identifying priority areas for forest landscape restoration in Chiapas (Mexico): An operational approach combining ecological and socioeconomic criteria. Landsc Urban Plan 94: 20-30

Orwa C, Mutua A, Kindt R, Jamnadass R, Anthony S. 2009. Agroforestree Database: a tree reference and selection guide version 4.0. World Agroforestry Centre, Kenya.
Purwanto, Maslina AFU, Mujiyo S, Minardi. 2018. Selecting species of vegetation and its land suitability evaluation for reclamation of post clay quarry in Kotabaru Regency, Indonesia. J Degrad Min Land Manag 6 (1): 1495-1503.

Rodreguesa, Gandolfia S, Navea AG, Aronson J, Barretoa TE, Vidala CY, Brancaliona PHS. 2011. Large-scale ecological restoration of highdiversity tropical forests in SE Brazil Ricardo Ribeiro Rodriguesa, For Ecol Manag 261: 1605-1613.

Salempa P, Noor A, Harlim T, Hariani N, Muharram, Sudding. 2014. The Antibacterial Properties of Bayur Tissues Extract (Pterospermum subpeltatum C.B. Rob). Jurnal Teknologi 69 (5): 87-89.

Salim A, Calfer CJP, McDougall C. 1999. Panduan Cara Pemberian Skor dan Analisis untuk Menilai Kesejahteraan Manusia. CIFOR, Bogor. [Indonesian]

Samsuri, Kusmana C, Jaya INS, Murtilaksono K. 2014 Restoration priority index development of degraded tropical landscape in Batang Toru watershed, North Sumatra, Indonesia. Biotropia 21: 77-85

Simien A, Penot E. 2011. Current evolution of smallholder rubber-based farming systems in southern Thailand. J Sustain Future 30: 247-260.

Stafford W, Birch C, Etter H, Blanchard R, Mudavanhu S, Angelstam P, Blignaut J, Ferreira L, Marais C. 2019. The economics of landscape restoration: Benefits of controlling bush encroachment and invasive plant species in South Africa and Namibia. Ecosyst Serv 27: 193-202.

Strobla K, Schmidta C, Kollmanna J. 2018. Selecting plant species and traits for phytometer experiments. The case of peatland restoration. Ecol Indicat 88: 263-273

Sudarmadji T and Hartati W. 2016. The process of rehabilitation of mined forest lands toward degraded forest ecosystem recovery in Kalimantan, Indonesia. Biodiversitas 17: 185-191.

Tipathi P, Karunakran G. 2013. Rambutan cultivation in Dillion WS (ed.). Fruit Production in India. Narendra Publishing House, New Delhi.

Wardhani MK. 2011. Analisis Kesesuaian Lahan Konservasi Hutan Mangrove di Pesisir Selatan Kabupaten Bangkalan Korespondensi. Program Sudi Kelautan Fakultas Pertanian Universitas Trunojoyo, Bangkalan. [Indonesian]

Wauters JB, Coudert S, Grallien E, Jonard M, Ponette Q. 2008. Carbon stock in rubber tree plantations in Western Ghana and Mato Grosso (Brazil). For Ecol Manag 255: 2347-2361.

Yusran, Rahmawati, Rapetempo S, Amrullah. 2012. Decay resistance of ten tropical wood species againts Ceratocystis polychroma Fungi. In: Lukmandaru G, Sulistyo J, Widyorini R, Tascioglu C, Xu J, Harris G (eds.). Proceeding of The $3^{\text {rd }}$ International Symposium of Indonesian Wood Reasearh Society (IWORs). Universitas Gadjah Mada, Yogyakarta, 3-4 November 2011.

Zaitunah A, Samsuri, Putri A. 2019. Landcover change analysis of besitang watershed, Langkat-North Sumatra. IOP Conf Ser 1282: 012090. DOI: 10.1088/1742-6596/1282/1/012090.

Zhanga J, Sua Y, Wua J, Liang H. 2015. GIS based land suitability assessment for tobacco production using AHP and fuzzy set in Shandong province of China. Comput Electr Agric 114: 202-211. 